\title{
Impression cytology of the ocular surface-research tool or routine clinical investigation?
}

Impression cytology, with cellulose acetate filters, was introduced in $1977^{1}$ as a minimally invasive conjunctival biopsy. It provides an alternative to conjunctival diagnostic excision biopsy or conjunctival smears made from scrapes taken with a blunt spatula. It was found that cellulose acetate filter paper pressed onto the ocular surface removed one to three cell layers of the surface epithelium, preserving its morphology and permitting the use of a limited range of histological techniques. ${ }^{2}{ }^{3}$ Impression cytology provides a flat mount of an area as large as the size of the applied filter paper with well preserved morphology. By comparison, conjunctival smears destroy much of the morphological information and conjunctival biopsies provide information on a relatively small sample of the surface epithelium, both because of the difficulty of preparing flat mounts and because of their necessarily small size. For these reasons impression cytology is ideal for sampling the corneal epithelium. Impression cytology is therefore the sampling technique of choice, providing the surface epithelium is the target tissue of interest rather than the basal epithelium or basement membrane.

Not surprisingly the technique has made an increasing contribution to our understanding of surface diseases of the eye. It has been modified by different authors. Initially it was used for qualitative and quantitative evaluation of the degree of squamous metaplasia and goblet cell numbers in ocular surface diseases such as dry eye, Stevens-Johnson syndrome, pemphigoid, and vitamin A deficiency, and the effect on these of various therapies. ${ }^{2-5}$ It has also been used to demonstrate corneal epithelial abnormalities, including the presence of goblet cells indicating a stem cell deficiency disorder ${ }^{6} 7$ and corneal squamous neoplasia. ${ }^{8}$ Papanicolaou or haematoxylin and periodic acid Schiff's stains are commonly used on these specimens. Typically, impressions are taken by pressing a disc or strip of filter paper onto the conjunctival and/or corneal surface in four quadrants from each eye. These may be placed on clear double sided tape on a microscope slide and fixed with a spray fixative or fixed in $95 \%$ alcohol and stained free floating. It is probable that the latter technique provides better resolution of the cytology although specimen handling is more cumbersome. Filter pore size affects the consistency of epithelial cell collection and the resolution of cell detail. Larger pore sizes collect cells better but with less well preserved cell detail. Surfactant treatment of the filter paper reduces cell pick up. Most authors have compromised by using surfactant free filter papers of a pore size between $0.22 \mu \mathrm{m}$ and $0.44 \mu \mathrm{m} .{ }^{9}$

This technique of cell collection has also been adapted for other ocular surface investigations. The filter paper can be fixed and prepared for transmission electron microscopy where it has been used to demonstrate the features of mucopolysaccharidosis ${ }^{10}$ and, in AIDS patients, viral particles in the conjunctiva. ${ }^{11}$ It has also been used to harvest cells from the cornea for investigation of DNA polymorphisms using the polymerase chain reaction. ${ }^{12}$
However, it is only recently that the technique has been adapted to allow immunohistochemistry and expand its role still further. ${ }^{13}$ Cellulose acetate filters are opaque and may have to be chemically cleared for cytological examination with xylene, destroying cell surface antigens. This, together with background fluorescence and staining of the filter paper, has precluded immunohistochemistry. Recently these problems have been addressed by using either Biopore membranes manufactured by one of the makers of cellulose acetate filters (Millipore Corp, Bedford, MA, USA) or by transferring impressions from the cellulose acetate filter to a gelatin coated glass slide The latter is a more convenient technique than the use of unmounted Biopore membranes which have proved difficult to handle. ${ }^{14}$ Using these techniques a variety of cell surface markers and cytokines have been detected in impression cytology specimens. ${ }^{13} 14$

All these methodologies have been invaluable as research tools but have not yet become routine diagnostic tools in most clinics because they are relatively cumbersome and time consuming for the clinician and pathologist alike. However, Thiel et al, in this issue of $B F O$ ( $\mathrm{p} 984)$, describe the use of mounted Biopore membranes that combine ease of use with good epithelial cell collection and permit application of all the potential investigational techniques described here. It is to be hoped that this technique will bring impression cytology from the clinical laboratory into routine clinical use.

JOHN DART

Corneal and External Disease Service, Moorfields Eye Hospital, City Road, London EC1V 2PD

1 Egbert PR, Lauber S, Maurice DM. A simple conjunctival biopsy. Am $\mathcal{F}$ Ophthalmol 1977;84:798-801.

2 Nelson DJ. Impression cytology. Cornea 1988;7:71-81

3 Tseng SCG. Staging of conjunctival squamous metaplasia by impression cytology. Ophthalmology 1985;92:728-33.

4 Natadisastra G, Wittpenn JR, West KP, Muhilal, Sommer A. Impression cytology for detection of vitamin A deficiency. Arch Ophthalmol 1987;105: cytolog

5 Kirkness CM, Adams GG, Dilly PN, Lee JP. Botulinum toxin A induced protective ptosis in corneal disease. Ophthalmology 1988;95:473-80.

6 Puangsricharern V, Tseng SC. Cytologic evidence of corneal diseases with limbal stem cell deficiency. Ophthalmology 1995;102:1476-85.

7 Nishida K, Kinoshita S, Ohashi Y, Kuwayama Y, Yamamoto S. Ocular abnormalities in aniridia. Am $\mathcal{F}$ Ophthalmol 1995;120:368-75.

8 Lee GA, Hirst LW. Ocular surface squamous neoplasia. Surv Ophthalmol 1995;39:429-50

9 Vadrevu VLD, Fullard RJ. Enhancements to the conjunctival impression cytology technique and examples of applications in a clinico-biochemical study of dry eye. $C L A O \mathcal{F}$ 1994;20:59-63.

10 Maskin SL, Heitman KF, Lawton AW, Yee RW. Diagnostic impression cytology for external eye disease. Cornea 1989;8:270-3.

11 Pastor SA, Shuster AR, Miller MM, Lam K-W. Use of impression cytology to demonstrate a retrovirus in AIDS patients with cytomegalovirus retinitis. to demonstrate a retroviru

12 Williams KA, Brereton HM, Aggarwal R, Sykes PJ, Turner DR, Russ GR, Coster DJ. Use of DNA polymorphisms and the polymerase chain reaction to examine the survival of a human limbal stem cell allograft. Am $\mathcal{F}$ Ophthamol 1995;120:342-50.

13 Pflugfelder SC, Crouse C, Pereira I, Atherton S. Amplification of Epstein-Barr virus genomic sequences in blood cells, lacrimal glands and tears from primary Sjogren's patients. Ophthalmology 1990;97:976-91.

14 Baudouin C, Haouat N, Brignole F, Bayle J, Gastaud P. Immunopathological findings in conjunctival cells using immunofluorescence staining of impression cytology specimens. Br f Ophthalmol 1992;76:545-9. 